\title{
Feasibility Profile of Endometrial Nodule Resection in the Uterosacral and Rectovaginal Ligament
}

\author{
Profil Kemungkinan Reseksi Nodul Endometriosis pada \\ Ligamen Uterosakral dan Rektovagina
}

\author{
Florencia Wirawan, Luky S Marwali \\ Fatmawati Hospital \\ Jakarta
}

\begin{abstract}
Objective: To know the feasibility of uterosacral and rectovaginal nodule resection in endometriosis patients who underwent laparoscopy surgery in Fatmawati Hospital.

Methods: Observational study was done by involving trained and experienced laparoscopist who performed deep infiltrating endometriosis (DIE) nodule resection laparoscopy on uterosacral and rectovaginal ligament. We observed on 35 patients which were histologically proven of DIE. We recorded the total procedure time, surgical complications occurred intra-operative, postoperative, and length-of-stay. The data were described descriptively.

Results: Mean (SD) of total laparoscopic procedure time including nodule resection was 200 (SD 52) minutes. There were two procedures $(5.7 \%)$ with intra-operative complications, one $(2.9 \%)$ with bowel injury which was converted to laparotomy, and the other one $(29 \%)$ with intra-operative bleeding so that the operator cancelled nodules resection. Mean (SD) on length of stay after the procedures was 2.5 (2.1) days. On follow up observation, there was not any postoperative complication.

Conclusion: Laparoscopic uterosacral and rectovaginal nodules resection in endometriosis patient is feasible to be done by trained and experienced laparoscopic surgeon.

[Indones J Obstet Gynecol 2017; 5-1: 42-45]
\end{abstract}

Keywords: endometriosis, laparoscopy, nodule resection

\section{Abstrak}

Tujuan: Untuk mengetahui tingkat kemungkinan prosedur reseksi nodul endometriosis pada ligamen uterosakral dan rektovagina pada pasien yang menjalani laparoskopi di RSUP Fatmawati.

Metode: Sebuah studi observasional prospektif dilakukan pada pasien endometriosis yang menjalani prosedur reseksi nodul via laparoskopi, nodul berlokasi di ligamen sakrouterina maupun rektovagina dan terbukti secara histologis. Lama tindakan, komplikasi selama operasi, pascaoperasi dan lama rawat inap dicatat. Data yang tersedia ditampilkan secara deskriptif.

Hasil: Rerata (Simpang Baku/SB) lama tindakan 200 (SB 52) menit. Terdapat dua kasus $(5,7 \%)$ dengan komplikasi intraoperasi yaitu cedera usus (2,9\%) dan operasi dialihkan ke laparotomi dan pembatalan reseksi nodul (2,9\%) dikarenakan perdarahan intraoperasi. Rerata (SB) lama rawat inap adalah 2,5 (SB 2,1) hari. Tidak ditemukan adanya komplikasi pascaoperasi.

Kesimpulan: Prosedur reseksi nodul endometriosis pada ligamen uterosakral dan rektovagina via laparoskopi dapat dilakukan oleh operator laparoskopi yang terlatih dan handal.

[Maj Obstet Ginekol Indones 2017; 5-1: 42-45]

Kata kunci: endometriosis, laparoskopi, reseksi nodul

Correspondence: Florencia Wirawan, florencia.wirawan@gmail.com

\section{INTRODUCTION}

Deep Infiltrating Endometriosis (DIE) is a disease marked by the ectopic presence of endometrium deeper than $5 \mathrm{~mm}$ beneath the peritoneal surface and it infiltrates different pelvic location. ${ }^{1}$ It is commonly found in the uterosacral ligament (USL), vagina; even, it can extend to intestine (bowel DIE), bladder, and ureter (urological DIE). ${ }^{1}$ Endometriosis occurs in one-third women who undergo surgery for chronic pelvic pain. ${ }^{2}$ Chronic pelvic pain often debilitates women with endometriosis for years; thus, it causes high risk of emergency department visit. This disease is associated with loss of productivity and physical also social weak- ness. ${ }^{2}$ Additional complaints in women with endometriosis-related pain can arise from comorbid pain, such as painful bladder syndrome (formerly called interstitial cystitis), migraine, and irritable bowel syndrome. ${ }^{2}$ We could prescribe medicine although it was often ineffective or only temporarily effective in controlling associated symptoms. ${ }^{3,5}$ Radical surgical resection of DIE lesion was the main treatment for this form of endometriosis.

Deep infiltrating endometriosis nodules surgery represents a real operative challenge due to common involvement of vital retroperitoneal structures including ureter, bowel, vessels, and nerves. Laparoscopy appears to be the most ideal 
tool to perform surgery and it offers a lot of advantages, such as possibility of magnification, accurate hemostasis, precise dissection, and careful handling of delicate tissue. ${ }^{4}$ Nevertheless, laparoscopic management of retroperitoneal endometriosis should not be undertaken by inexperienced surgeon. Good knowledge of pelvic retroperitoneal anatomy is a prerequisite for radical and uncomplicated removal of DIE nodules. ${ }^{4,5}$ The nodules of DIE were commonly found at uterosacral ligament (USL) compared with rectovaginal location, followed by bowel and urological involvement. ${ }^{6}$ If the nodules are located on uterosacral or rectovaginal ligament, nodules resection procedure can be performed more safely than other location of nodules. Meanwhile, if the nodules have bowel or urological involvement, endometriotic nodules resection requires more advanced technique with higher risk of organ injury. Therefore, in this study, we would like to determine the feasibility of uterosacral and rectovaginal nodule resection (without bowel and urological involvement) who underwent laparoscopy surgery in Jakarta.

\section{METHODS}

All nodule resection procedures (involving uterosacral and rectovaginal) in endometriosis patients which had been proved by histological finding were recruited from Fatmawati General hospital as referral centre. The study period was from September 2015 to May 2016. All patients were followed-up and evaluated to create endometriosis nodule resection feasibility profiles which included total procedure time, intraoperative complications (bowel, bladder, ureteral, vascular injury, massive blood loss, cancelled nodule resection or converted to laparotomy), post-surgery complications (fever, transient urinary retention, incontinence, ureterovaginal or rectovaginal fistulas), and hospital's length of stay. All laparoscopic nodule resection procedures were performed by trained and experienced laparoscopic surgeons. In this study, all surgeons did the procedure through same technique described by Wattiez. ${ }^{6}$ The technique consisted of general and specific strategy. First step in general strategy was to hold adhesiolysis so that it would describe better exposure to the pelvic anatomy, followed by ureter identification and pararectal space dissection. In specific strategy, the surgeon had to resect all visible nodules in uterosacral and rectovaginal ligament. In case of any bladder, ureteral, or bowel involvement, we performed the procedure through multidiscipline approach.

\section{RESULTS}

Between September 2015 and May 2016, we obtained 35 laparoscopic uterosacral and rectovaginal nodule resection procedure. It included $23(65.7 \%)$ nodules located only at uterosacral ligament, 6 (17.1\%) nodules located only at rectovaginal, and the other $6(17.1 \%)$ women having nodule at both sites (Table 1). The mean (SD) of total laparoscopic procedure time which included nodule resection was 200.4 (SD 52.5) minutes (Table 2). There were two procedures $(5.7 \%)$ with intra-operative complications, one $(2.9 \%)$ with bowel injury which was converted to laparotomy; and the other one $(2.9 \%)$ with intra-operative bleeding causing the cancellation of nodule resection (Table 3). The mean (SD) of length-of-stay in hospital after finishing procedures was 2.5 (2.2) days (Table 4). On follow-up observation, we did not find any postoperative complication.

Table 1. Location of Nodules

\begin{tabular}{lcc}
\hline \hline \multirow{2}{*}{ Location of Nodules } & \multicolumn{2}{c}{ Responses } \\
\cline { 2 - 3 } & $\mathbf{N}$ & $\mathbf{\%}$ \\
\hline Uterosacral Ligament (USL) & 23 & $65.7 \%$ \\
Rectovaginal Ligament & 6 & $17.1 \%$ \\
Both USL and Rectovaginal Ligament & 6 & $17.1 \%$ \\
Total & 35 & $100.0 \%$ \\
\hline \hline
\end{tabular}

Table 2. Time of Procedure

\begin{tabular}{cccc}
\hline \hline Min (min) & Max (min) & Mean & Std. Deviation \\
\hline 100 & 420 & 200.4 & 52.5 \\
\hline \hline
\end{tabular}

Table 3. Surgical Complication

\begin{tabular}{lc}
\hline \hline Complication & N (\%) \\
\hline Intra-surgery Complication & $1(2.9)$ \\
Bowel Injury & $0(0)$ \\
Bladder Injury & $0(0)$ \\
Ureteral Injury & $0(0)$ \\
Vascular Injury & $0(0)$ \\
Massive Blood Loss & $1(2.9)$
\end{tabular}




\section{After Surgery Complication}

\begin{tabular}{ll} 
Fever & $0(0)$ \\
Urinary Retention & $0(0)$ \\
Incontinence & $0(0)$ \\
Ureterovaginal Fistula & $0(0)$ \\
Rectovaginal Fistula & $0(0)$ \\
\hline \hline
\end{tabular}

Table 4. Length of Stay in Hospital

\begin{tabular}{cccc}
\hline \hline Min (min) & Max (min) & Mean & Std. Deviation \\
\hline 2 & 14 & 2.5 & 2.2 \\
\hline \hline
\end{tabular}

\section{DISCUSSION}

The degree of pain related to severity of disease is varied among patients. Some cases of mild endometriosis can be associated with significant pain and other women with severe endometriosis may experience little or no pain. Meanwhile, $5 \%$ of patients with DIE were pain-free. Pain can derive from compression or infiltration of specific nerves by the ectopic endometrial growth. The anatomical position of the lesion on the organ is able to prevent or interfere with its function. Histological evaluation of DIE with severe pain is related to higher proportion of intraneural and perineural infiltration. Nerves have close relationship with the endometriotic nodules and the fibrotic tissue; thus, there is a relationship between endometriotic lesions and pain. The cytokines and growth factors (estradiol, prostaglandins, and nerve growth factor) associated with endometriosis have correlation with pain sensation. In addition to that, current studies proposed that endometriosis lesions could stimulate peripheral nerve fibers to sensitize the central nervous system and lead to phantom pains in the absence of lesion.

All patients in this study had already received hormonal therapy; however, it failed to reduce the symptoms. Radical surgical resection of DIE lesions was the main treatment for this form of endometriosis. Open access to posterior DIE nodule represents an operative challenge due to common involvement of vital retroperitoneal structures. Careful dissection is necessary to restore pelvic anatomy and preserve function. ${ }^{4}$ In fact, there is possibility of unpredictable complexity intra procedure; therefore, we have to be prepared.
In this study, there was one case of bowel injury. This injury happened during the dissection of bowel from the rectovaginal adhesion. The surgeon failed to identify the correct plane during dissection. As bowel injury might happen anytime, we suggested bowel preparation before the procedure. ${ }^{7}$ Other intra-operative complication found in this study was intra-operative bleeding obscuring the operative field. The surgeon decided not to resect the nodules because it would increase the risk of the surgery afterwards. Cancellation of nodules resection should not be done under any circumstances.

A multidisciplinary surgical team led by a experienced gynecologist has to work together in complex cases with urologist, gastrointestinal surgeons, and/or general surgeons. All of them may play an important role in providing adequate treatment and as well as increasing the likelihood of providing consistent, evidence-based, and cost efficient care. ${ }^{8,9}$

\section{CONCLUSION}

Laparoscopic uterosacral and rectovaginal nodules resection in endometriosis patient is feasible to be performed by trained and experienced laparoscopic surgeon although multidisciplinary team approach should be joined for severe cases.

\section{REFERENCES}

1. Cornillie FJ, Oosterlynck D, Lauweryns JM, Koninckx PR. Deeply infiltrating pelvic endometriosis: histology and clinical significance. Fertil Steril. 1990; 53: 978-83.

2. Stratton P, Berkley KJ. Chronic pelvic pain and endometriosis: Translational evidence of the relationship and implication. Hum Reprod. 2010; 17(3): 327-46.

3. Moawad NS, Caplin A. Diagnosis, management, and long-term outcomes of rectovaginal endometriosis. Int J Women Health. 2013; 5: 753-63.

4. Protopapas A, Giannoulis G, Chatzipapas I, Athanasiou S, Grigoriadis T. Posterior Deep Infiltrating Endometriotic Nodules: Operative Considerations according to Lesion size, Location, and Geometry, during One's Learning Curve. Hindawi Publish Corp. 2014: 8.

5. Vignali M, Bianchi S, Candiani M, Spadaccini G, Oggioni G, Busacca M. Surgical treatment of deep endometriosis and risk of recurrence. J Minimal Invasive Gynecol. 2005; 12: 508-13. 
6. Nassif J, Trompoukis P, Barata S, Furtado A, Gabriel B, Wattiez A. Management of deep endometriosis. Repro Biomed Online. Elsevier. 2011; 23: 25-33.

7. Angioni S, Peiretti M, Zirone M, Palomba M, Mais V, Gomel V. Laparoscopic excision of posterior vaginal fornix in the treatment of patient with deep endometriosis without rectum involvement: surgical treatment and long-term follow up. Hum Reprod. 2016; 21(6): 1629-34.
8. Avila I, Costa LMP, Soto R. Safe multidisciplinary approach in deeply infiltrating endometriosis (DIE): Is it feasible? JBRA Assist. Reprod. 2014; 18(4): 139-43.

9. The practice committee of ASRM. Treatment of pelvic pain associated with endometriosis: committee opinion. Fertil Steril. 2014; 101: 927-35. 